\title{
Nowcasting Regional Unemployment Rate in Denmark Using Google Trends to Develop Mining Sector
}

\author{
Mihaela SIMIONESCU ${ }^{1 *}$
}

Author's affiliation and address:

${ }^{1}$ Institute for Economic Forecasting, Romanian Academy, 050711, 13, Calea 13 Septembrie,

Bucharest, Romania

e-mail: mihaela.simionescu@ipe.ro

\section{*Correspondence:}

Mihaela Simionescu, Institute for Economic Forecasting, Romanian Academy, 050711, 13, Calea 13 Septembrie, Bucharest, Romania e-mail: mihaela.simionescu@ipe.ro

\section{Acknowledgement:}

This research is part of the research plan of the Institute for Economic Forecasting of the Romanian Academy for 2021 with the title: "The status of the Romanian migrants on the labour market of other EU countries".

\section{How to cite this article:}

Simionescu, M. (2021). Nowcasting Regional Unemployment Rate in Denmark Using Google Trends to Develop Mining Sector. Acta Montanistica Slovaca, Volume 26 (3), 498-511

DOI:

https://doi.org/10.46544/AMS.v26i3.09

\begin{abstract}
Considering the recent tendencies in the utilisation of Internet data, COVID-19 pandemic and the EU target to develop a competitive digital economy, the aim of the paper is related to nowcasting the regional unemployment rate in Denmark using specific keywords for Google searches ('job', 'Jobnet', 'jobindex.dk' and 'ofir.dk') to predict an economic crisis. Compared to previous studies that describe unemployment using Internet data, this paper provides a regional insight in nowcasting unemployment in Denmark using various panel data models. According to the panel nonlinear autoregressive distributed lag (ARDL) models, a significant short-run and long-run connection between the quarterly unemployment rate at NUTS 2 level in Denmark and the mentioned keywords in the period 20082020. The increase by $1 \%$ in job searches lowers the unemployment rate by 0.055 to 0.061 percentage points in the short-run. However, in the long-run, the amplitude of these regimes is higher (by 0.143 to 0.642 percentage points), showing that more searches for jobs in Denmark will significantly reduce the unemployment rate. The results suggest that the combination between official statistics and data collected using Google Trends has the capacity to improve the unemployment predictions in Denmark, and it is recommended in the short-run planning of the government. The quarterly predictions for economic growth in 2021 could be used to anticipate a potential economic crisis in Denmark. This country has no active mines, and quarrying plays a less significant role in the national economy, but in the context of a future crisis, this sector should develop, and Google Trends could be an efficient tool for policymakers and for people searching for a job in this sector.
\end{abstract}

Keywords

Google Trends, jobs, panel ARDL model, unemployment rate

(C) 2021 by the authors. Submitted for possible open access publication under the terms and conditions of the Creative Commons Attribution (CC BY) license (http://creativecommons.org/licenses/by/4.0/). 


\section{Introduction}

A lower unemployment rate is a target for Denmark's policies due to benefits related to public finance, social and distributional objectives. Denmark presents low structural unemployment due to the flexicurity model and more reforms implemented from the mid-1990s (Andersen, 2019). Our hypothesis is that the maintenance of a low unemployment rate in Denmark is also due to the benefits of Internet searches for a job.

Even if the Danish economy was severely affected by the Great Depression (2008-2013), the unemployment rate remained below the average of the euro area. Even if the occupation rates are high, working hours are lower compared to OECD countries (Andersen, 2019). Moreover, Erhvervsråd (2018) noticed an increase in the number of persons without a job, not in education or without public social support during 2010-2017 by 30000 people. Major reforms were undertaken in 2006 and 2011 by increasing the age for retirement due to longevity growth (Knudsen et al., 2017). These reforms and those in the last decade had direct consequences on the labour market by forcing young people to enter earlier on the labour market and older people to remain more time actively. Therefore, we can conclude that the reforms had a single target: the qualitative and quantitative growth of the labour force. The policy debates centred on the level of taxation that might make the income too low to motivate keeping a job. Few incentives were implemented to reduce unemployment: residence in Denmark is requested for non-EU citizens and other conditions to benefit from social assistance (level of education, age, activation, cap on support, and employment) (Andersen, 2019). The last few years have been characterised by social and labour policies focused on unemployment prevention, which is more beneficial in the long-run.

Valuable active policies were introduced in 2015. Before this, any unemployed was obliged to post the CV on a dedicated website in the first month and go to job interviews, but these requirements were formal and without efficient results in terms of insertion in the labour market. The reform in 2015 made the active labour policy more flexible by focusing on suitable jobs for a candidate and faster employment due to fiscal incentives. The counselling to get a suitable job is a key point of this reform. Various evaluations of the impact of active labour policies on unemployment rates were made, but the results are mixed (Jespersen et al., 2008).

According to the "Early start" programme, the early intervention had better effects on unemployment reduction compared to the unemployed that were the subject of active measures of intervention (Rosholm \& Svarer, 2009). The proper effects were shown by less period of expectation until employment.

It is clear that the level of education and counselling have significant effects in reducing unemployment in Denmark, but none of the studies assessed the contribution of Internet searches for a job to unemployment reduction. In this context, this research covers this gap from the literature. Various policy initiatives have their own role in reducing the labour force tensions like motivational factors, but the effective actions for searching for a job reflect unemployed behaviour or attitudes of people looking for a better job than actual one.

Unemployment is counted among the key macroeconomic indicators, nowcasting this variable being necessary for macroeconomic forecasting. The latest world concerns starting from the Great Recession (20082013), euro debt crisis and COVID-19 pandemic affected the unemployment dynamics in Europe, despite significant cross-country differences (Claveria, 2019). Many Danes faced lay-offs because of the coronavirus pandemic. Denmark shut down on March 11, 2020, which enhanced unemployment that reached a maximum level at the beginning of July 2020. Even Copenhagen reached an unemployment rate of $7 \%$ in August, but this issue affected North Denmark (Nordjylland region).

Even if few studies have analysed the impact of job searches in a zone on unemployment nowcasts (Caperna et al., 2020; D'Amuri \& Marcucci, 2017; Mulero \& Garcia Hiernaux, 2020; Simionescu \& Zimmermann, 2017; Vicente et al., 2015; Askitas \& Zimmermann, 2009), the disparities between regions were not taken into consideration in predicting the unemployment rate. Only Simionescu (2020) employed a regional analysis for studying unemployment in Romanian counties using panel data models in the period 2004-2018. However, the analysis did not take into account the long and short-run connection established between the unemployment rate and Google indexes, which is the aim of our paper. In this context, panel ARDL models are built to explain this indicator in Denmark regions in the period 2008-2020.

Google Trends has served as a data-provisioning tool since 2008 to describe the population views reflected in all searches associated with certain queries identified by keywords. The applications of Google search activity are related to the dynamics of various macroeconomic indicators, provision of nowcasts and predictions. In most cases, the values of the unemployment rate are provided quite late and in various provisional forms until the final values. For example, the official values of macroeconomic indicators did not anticipate the Great Depression. In this context, the unemployment rate nowcasts could provide in time details about employees and employers behaviour (Simionescu \& Zimmermann, 2017) and help the government in proposing labour force policies to avoid high unemployment.

Real-time forecasts for unemployment based on Google trends could be used to predict economic growth in Danish regions. The first difference model specification of Okun law is used to explain the change in economic growth in regions. If most or all the regions will register an economic decline in two successive quarters, the first signal of an economic crisis in this country is detected. 
There are no active mines in Denmark, and this country lacks economically exploitable metallic mineral resources. The extractive sector is based on nonmetallic minerals like sand, salt, chalk, gravel, stone, and limestone that are utilised mostly in building and various construction projects. However, in the context of a new global economic crisis determined by the COVID-19 pandemic, Denmark should have planned mines to develop this sector and implement the successful model of other Nordic countries. Countries like Norway, Sweden and Finland have already political initiatives to promote mining for achieving sustainable development.

After providing arguments for the utility of Internet searches for jobs in reducing unemployment in Denmark, some results of previous studies in other countries are presented in the next section. The utility of our approach is justified by the empirical results supposing the nowcasting of the unemployment rate based on a nonlinear panel ARDL model.

\section{Literature Review}

Given the negative consequences of the COVID-19 pandemic on global labour markets, unemployment remains a key indicator for policymakers, the public, and researchers. The new challenges brought by the pandemic in terms of digital transformation and the green economy at the European level enhanced the efforts to develop the digital economy. Searching for a job using digital devices supposes at least minimum digital skills. On the other hand, national digitalisation requires the development of digital skills for the labour force in order to practice future jobs.

There is an increasing interest in providing real-time data that could priory suggest the changes in unemployment (Fondeur \& Karamé, 2013). The EC regulation concerning the provision of business statistics in the short-term at the EU level requested the faster release of essential indicators for improving the short-run economic analyses (Naccarato et al., 2015) with the involvement of the statistical offices in each country. Given these European requirements, we propose as an efficient solution the use of Google Trends data to nowcast unemployment and our application is presented for Denmark, the country with the best digital performance in Europe.

Before the facility of Google activity data, Ettredge et al. (2005) employed Internet search to predict the US unemployment rate using the keywords proposed by WordTracker's Top 500 Keyword Report: namely job search, job listings, employment, jobs, resume, and monster.com.

The seminal study conducted by Askitas and Zimmermann (2009a) proved firstly the relevant relationship between German monthly unemployment and a few Google keywords during January 2004 - April 2009 based on vector error correction models: unemployment rate, unemployment office or agency, most popular search engines in Germany, and Personnel Consultant. Granger causality was checked like in the study of Su (2014) for China, but in our paper, we will identify short-run and long-run connections using panel data. The second paper of Askitas and Zimmermann (2009b) came up with re-estimation based on keywords like job search, labour office, and shortterm work to assess forecast performance.

Literature research on this subject has not defined whether conventional data sources could be fully replaced or better combined with Internet data. Some authors achieved better outcomes when integrating the data in their models (see Chadwick \& Sengül, 2017; Naccarato et al., 2018). In our research, we used econometric models based on Internet data and official ones to explain the unemployment rate.

The approach proposed by Askitas and Zimmermann (2009a) for the German unemployment rate was taken over in the studies for other countries. Our paper that describes the unemployment rate based on Internet data represents Denmark's first research in this field. The advantages are related to essential information that is not provided by business cycle indicators and various types of time-series models. Some of these studies for the unemployment rate were made for developed countries like G7 countries (Davalos, 2015), Norway (Anvik \& Gjelstad, 2010), Italy (D'Amuri, 2009; Naccarato et al., 2015; Naccarato et al., 2018), the UK (McLaren and Shanbhogue, 2011), US (Choi \& Varian, 2009; Choi \& Varian, 2012), Canada (Dilmaghani, 2019), Turkey (Chadwick \& Sengül, 2015), France (Fondeur \& Karamé, 2013), China (Su, 2014), Israel (Suhoy, 2009), Spain (Vicente et al., 2015), Brazil (Lasso \& Snijders, 2016), but also for less developed countries like Ukraine (Oleksandr, 2010).

The majority of these researches depend on a large volume of Google questions. For instance, four groups were employed by Askitas \& Zimmermann (2009a) and eight keywords with the word or were proposed. Principal components analysis could be applied for reducing the queries number. The factors may be viewed as indicators in econometric models. This methodology was utilised by Choi and Varian (2009) and by D'Amuri and Marcucci (2009), the latter restricting to searches for jobs in the US. The Google records related to jobs were the most reasonable solution to foresee the unemployment in the USA.

Google Trends is the most utilised instrument to gather Internet data to explain the unemployment rate, the keywords being written in that country language. Before data collection, the country in which searches are done should be set. For US and UK, the most frequently used keyword is jobs (D'Amuri \& Marcucci, 2017). A similar keyword was used in this research for Denmark: "job". Besides this term, McLaren and Shanbhogue (2011) used 
for the UK other keywords to explain the unemployment rate based on autoregressive models: unemployment, unemployment benefit, unemployed, JSA, and Jobseeker's Allowance. Other recent studies used Google Trends to anticipate unemployment evolution in Canada for young people (25-44 years old) (Dilmaghani, 2019) and the unemployment rate in Spain (Mulero \& Garcia Hiernaux, 2020). In this context, Dilmaghani (2019) confirmed that the intensity of online leisure activities explains Canadian unemployment. Similar studies were conducted for countries in Latin America. For example, Lasso and Snijders (2016) proved a significant connection between the unemployment rate in Brasil and indicators based on Internet data, observing significant seasonal patterns. A similar study for Portugal used: décimo terceiro salário $\left(13^{\text {th }}\right.$ salary), empregos (jobs), and seguro desemprego (unemployment).

Many studies have analysed the South-western countries, especially Italy. D'Amuri (2009) and D'Amuri and Marcucci (2009) indicated that the most well-known keywords for employment searches in Italy are: offerte di lavoro, meaning job offers. This expression was utilised by Francesco (2009) to demonstrate that various models utilising Google search data beat different sorts of predictions for unemployment in Italy. In addition, Naccarato et al. (2018) and Naccarato et al. (2015) additionally utilised this keyword. Naccarato et al. (2015) put into association this term with unemployment data from Labor Force Office of Italy, finding a co-integration between factors. This keyword was also utilised by Naccarato et al. (2018) to anticipate youth unemployment in the same country utilising monthly information. The authors employed an ARIMA model based on official statistics and a VAR linking official data with Google Trends based on searches for offerte di lavoro (job offers). The predictions based on Google Trends data were better than those employing only official data. In the case of Spain, Vicente et al. (2015) explained unemployment using the same tool for keywords showing job offers: oferta de trabajo and oferta de empleo. In the case of France, Fondeur and Karamé (2013) utilised inquiries for the word emploi that implies occupations, but also employment in French to predict youth unemployment (15-24 years) using methods like MLE and Kalman filter.

Comparisons were also made for South-western countries by Barreira et al. (2013), who proved the ability of Google Trends indicators to improve unemployment rate forecasts in the case of France, Italy, and Portugal, but not for Spain. The employed keywords are linked to unemployment and associated benefits in Italy (INPS disoccupazione, disoccupazione, and disoccupazione ordinaria), France (allocations chomage, chomage, and indemnites de chomage), Portugal (subsidio desemprego and desemprego) and Spain (subsidio de desempleo, prestacion desempleo, and desempleo). INPS represents the Italian National Institute for Social Security.

Few papers analysed states belonging to Central and Eastern Europe, where the Internet penetration rate is lower, which makes the connection between unemployment and Google indicators irrelevant for some countries. For example, in the case of Visegrad countries (V4 countries), Pavlicek and Kristoufek (2015) obtained a significant link between monthly unemployment and indicators based on searches for jobs and work only for Czechia and Hungary from January 2004 to December 2013. The used keywords were: práce and prace (Czech Republic and Slovakia), práca and praca (Poland), állás and munka (Hungary). Limited Internet access made this correlation insignificant also for Ukraine (Oleksandr, 2010).

In the case of Turkey, Chadwick \& Sengül (2015) showed the superiority of Google approach in explaining the evolution of unemployment in nonagricultural sectors, where the keywords are based on Google Insights for Search: işsizlik sigortası (unemployment insurance), İşsizlik (unemployment), iş arama (searching for a job), iş ilanları (job announcements), CV (CV) and kariyer (career).

It is interesting that Nordic countries in Europe did not make the subject of this type of researches, but this analysis is more relevant for these states since the Internet penetration is higher than in other countries. This study is the first conducted for Denmark in the context of European Commission targets to achieve a single digital market to ensure a competitive European economy.

\section{Data and Specific Methodology}

Panel data method is used to describe the evolution of the unemployment rate in Denmark at the regional level (NUTS2 level). This method allows for the control of regional heterogeneity and detects unobservable features, providing more reliable estimations (Baltagi, 2005). This study refers to the NUTS2 counties in Denmark (Hovedstaden, Sjælland, Syddanmark, Midtjylland and Nordjylland) in the period 2008-2020 for quarterly data. The Google searches for the period 2004-2007 were not significant for the analysed keywords. The GMM estimator is not suitable for this research since the volume of the panel is quite small. Therefore, an ARDL analysis is conducted since this method could be applied for panel data with a longer period (13 years) and a small number of cross-sections (5 regions). Denmark was chosen in this analysis for two arguments that support significant steps in implementing the digital economy in this country:

Denmark has been the leading country in what concerns digital performance in the EU since 2014 due to: digitalisation of the public sector through Agenda for Digitalisation launched in 2011, welfare technology, large business investment in IT resources that have grown labour productivity (European Commission, 2019). 
Denmark is the European country with the highest Internet penetration in 2020 (98\%), according to Statista data; Denmark is among the countries with the maximum value of DESI (Digital Economy and Society Index) at the world level according to the latest data from 2020 (other countries with the same performance are Finland, Sweden and Netherlands) (Foley et al., 2020).

Considering these achievements for Denmark, it could serve as a model of a successful digital economy where we expect to nowcast the unemployment rate with high accuracy. In this context, the unemployment rate will be explained at the regional level using people's searches for jobs on Google.

The data of this study are based on different sources. Data for the quarterly unemployment rate and GDP in a million PPS are provided by Labour Force Survey microdata and Eurostat. The regional GDP in PPS withdraws the differences in prices, while the GDP per inhabitant makes possible comparisons between regions, allowing the eligibility of NUTS 2 zones in the EU structural policy.

NUTS 2 unemployment rate is computed as unemployed persons between 15 and 74 years old as the percentage of the active population from an economic point of view (employed plus unemployed). This indicator is provided by the EU Labour Force Survey. Three criteria should be fulfilled simultaneously for unemployed people: they do not have a job during the reference week, they are available for work at that moment and seek a job or found it and will start to work within 3 months.

The microdata for Google searches based on keyword 'jobs' are provided by Google Trends. Other keywords were analysed, but 'job' was at the top of preferences: 'Jobnet', 'jobindex.dk' and 'ofir.dk'. A significant volume of data was not obtained for the keyword 'Workindenmark.dk' in the entire period. We select 'job' instead of 'jobs' because we have more searches for 'job'.

The keyword related to jobs was previously used by other authors, but neglecting the regional approach that is presented in this paper: Lasso \& Snijders (2016) for Brasil (empregos=jobs), McLaren \& Shanbhogue (2011) for the UK (jobs), Chadwick \& Sengül (2015) for Turkey (iş aramak=looking for a job) and Askitas \& Zimmermann (2009a) for Germany (jobboerse = job market). Moreover, we have used specific websites as keywords based on Google Trends indications.

The first difference model specification of Okun law is used to explain the variation in economic growth in the period 2021:Q1-2021:Q4:

$Y$ - logarithm of real GDP

$$
Y_{i t}-Y_{i t-1}=\alpha_{i}+\beta_{i} \cdot\left(u r_{i t}-u r_{i t-1}\right)+\varepsilon_{i t}
$$

$U$ - unemployment rate

$\alpha, \beta$ - parameters

$t$ - index for time, $i$ - index for region

The parameters of the models for all regions are estimated. As the economic recession is declared when two successive quarters of negative economic growth are registered, two-quarters-ahead forecasts of changes in output are predicted using unemployment rate forecasts based on econometric models using Google Trends indexes. If two quarters with negative economic growth are predicted in all or most of the regions, the global economic crisis is detected.

The analysed period in this research was restricted by Google search data availability. We selected GDP in PPS as a control variable based on economic theory. The economic connection between output and unemployment is reflected by Okun's law. Kargi (2016) showed evidence for the inverse and significant but quite weak relationship between GDP and unemployment in Denmark in the period 1987-2012. However, no regional approach has been proposed yet for Denmark, which is the subject of this study.

Several quantitative methods are employed to check the link between unemployment and Google indexes related to job searches in the Danish regions. Nonlinearity and both long and short-term connections are considered. The panel ARDL model is employed to identify the long-and short-term relationships between variables following the approach of Pesaran et al. (1999). In this case, the contemporaneous limit is managed by using the common correlated effect mean group (CCEMG) and CS-ARDL of common correlated effect pooled mean group (CCEPMG). Threshold effects are not considered in this research.

It is interesting to compare the situation of unemployment in each region in Denmark before and during the COVID-19 pandemic. The growth in the unemployment rate because of measures specific to a pandemic is higher in the North and lower in the Center of Denmark. 


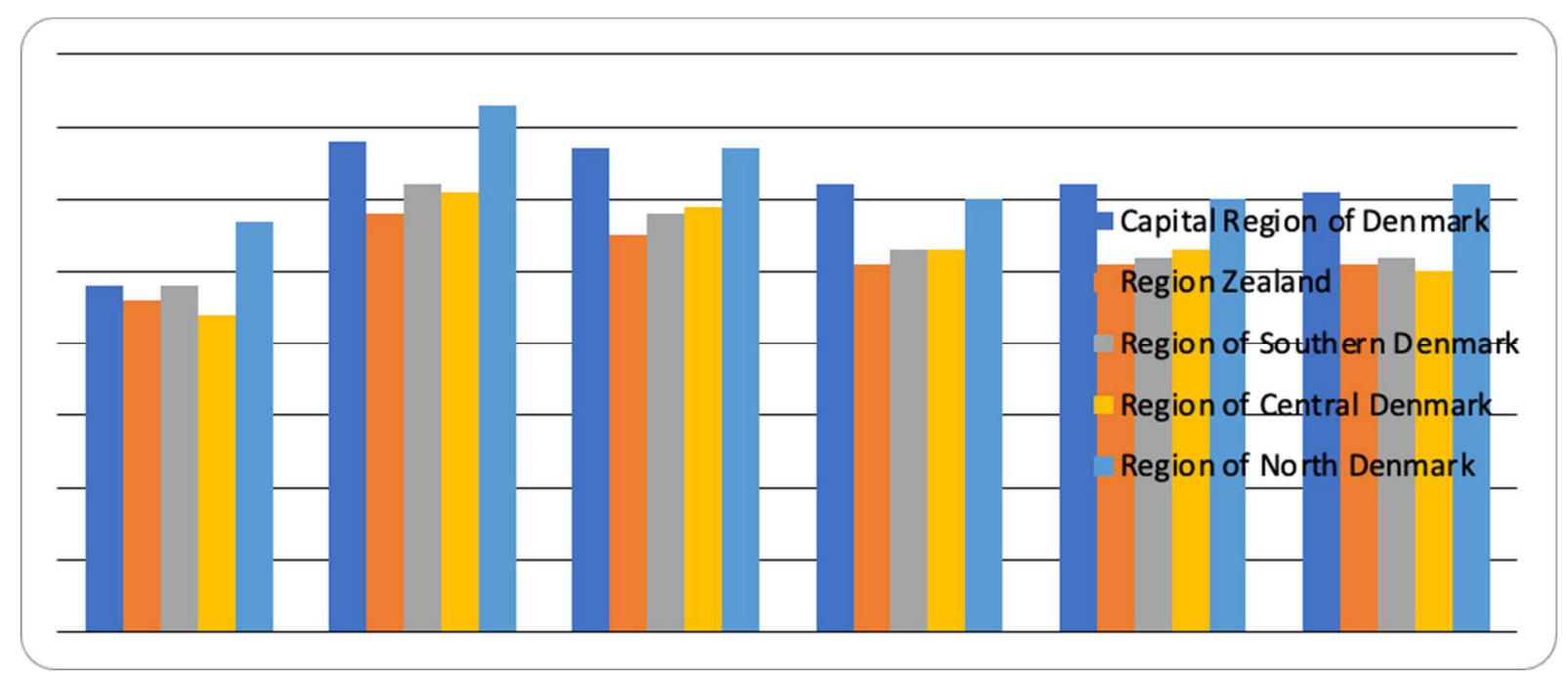

Fig. 1. The unemployment rate in the regions of Denmark before and after the COVID-19 outbreak in 2020

Pandemic affected the Danish labour market at the regional level by increases in the unemployment rate. These changes could be observed in real-time by correlating the Internet searches for jobs with the unemployment rate.

Google Trends releases a chronological series/ panel data index to show the queries level corresponding to users that searched on Google a certain keyword in a geographical area (a certain country or area in that state). The query index is a ratio of two elements: the overall query level for a particular keyword in that region and the final number of all queries in the same geographical surface in a mentioned period. It is realised normalisation to 100 is in case of the greatest query share in that specific period. On the other hand, the normalisation to zero is done for that query share placed at the beginning of the period (Choi \& Varian, 2012).

Google Trends instrument provides benefits but also limits indicated by Askitas (2015). The advantages are related to "sessionization" that reduces typing errors, usefulness repetitions, rewrites, correct identification of region using the computer's IP address, the identification of the relevant keywords in a zone, the use of a representative subsample of data. However, this procedure provides an aggregate image of people's behaviour related to a topic, and there are few details about the methodology (Simionescu \& Zimmermann, 2017). The results are conditioned by the Internet penetration rate in that country, but in our case, Denmark presents a high penetration rate that makes the results reliable.

Few preliminary tests were applied before estimation: panel unit root tests, various tests for cross-sectional dependence and panel co-integration tests. Firstly, unit root tests are applied to check for non-stationarity in data sets, assuming the non-stationary character of panel data as a null hypothesis. The existence of unit root is verified by applying several tests: Levin-Lin-Chu test (it assumes lack of heterogeneity in case of autoregressive coefficient), Im-Pesaran-Shin test (it allows for heterogeneity) and second-generation test known as CIPS (it admits the contemporaneous cross-sectional correlation). The lag length is chosen based on information criteria. The Bayesian-Schwarz criteria will be considered.

The existence of cross-sectional dependence is also verified using the Cross-Sectional (CD) Pesaran test. The estimation process in the case of panel data supposes independent errors in cross-sections. On the other hand, there are practical cross-country effects that determine cross-sectional dependence caused by spatial distribution, economic and political spill-over (Gaibulloev et al., 2014). In this context, CIPS and CD tests were employed to check this assumption for errors.

Starting from the results based on tests of non-stationarity, two-panel co-integration tests were employed. In the case of non-stationary data, the co-integration is checked using the Pedroni test and Westerlund test to identify a possible long-term association between variables.

The Westerlund (2007) test uses four approaches under the null assumption of no co-integration. If this assumption is rejected, there is at least one unit presenting co-integration.

There are seven tests proposed by Pedroni (1996), three of them being based on between-dimension approaches and four of these tests using within-dimension methods. The independent idiosyncratic error across units is corrected using the generalised least square correction.

The panel Autoregressive Distributed Lag model (called panel ARDL) is built in the case if no co-integration was detected with specific tests. The nature of the data series does not allow us to utilise the GMM estimator. The relationship between the unemployment rate and Google indexes is analysed using specific estimators presented by Pesaran et al. (1999): mean group (denoted by MG), pooled mean group (known as PMG) and two-way fixed effect (TWFE).

We will start from the ARDL model: 


$$
\log \_u r_{i t}=\alpha_{i}+\sum_{l=1}^{p} \beta_{0} \log \_u r_{i t-l}+\sum_{l=0}^{q} \beta_{1} \log \text { index }_{i t-l}+\sum_{l=0}^{q} \beta_{2} \log \_G D P_{i t-l}+e_{i t}
$$

$i$ is the index for region and $t$ is the index for time, $u r$ - unemployment rate, index - Google Trends index associated to a certain keyword, GDP is the control variable.

After parameterisation, the previous equation becomes:

$$
\begin{aligned}
\Delta \log \_u r_{i t}= & \alpha_{i}+\Phi_{i}\left(\log \_u r_{i t-l}-\theta_{1} \log { }_{-} i n d e x_{i t-l}-\theta_{2} \log \_G D P_{i t-l}\right)+\sum_{l=1}^{p-1} \lambda_{i l} \Delta \log \_u r_{i t-l} \\
& +\sum_{l=0}^{q-1} \lambda_{i l}^{\prime} \Delta \log { }_{-} G D P_{i t-l}+\sum_{l=0}^{q-1} \lambda_{i l}^{\prime \prime} \Delta \log \_G D P_{i t-l}+e_{i t}
\end{aligned}
$$

In this case, $\lambda, \lambda^{\prime}, \lambda^{\prime \prime}$ represent the short-run parameters associated to lagged endogenous factor, index and GDP, respectively. $\theta 1$ and $\theta 2$ are the long-term parameters for index and GDP. The adjustment speed is represented by $\Phi_{i}$ (Pesaran \& Smith, 1995).

The PMG estimator considers homogenous long-run equilibrium across regions and heterogeneous short-run relationships. The heterogeneity associated with regions could be explained by different responses to external shocks. The heterogeneous short and long-run connection is promoted by the MG estimator that is consistent only for many regions in the sample. In the case of a few regions, like in this analysis, the MG estimator becomes sensitive to any permutations in case outliers presence and small model (Favara, 2003). TWFE estimator works under homogeneity across regions, restricting the speed of adjustment, the slope of the regression and the shortrun parameter. In this case, we assume that all the regions have the same response to long and short term shocks. Moreover, Baltagi (2000) explained that this method supposes simultaneity bias in the case of a small set of data because of the endogeneity between explanatory variables with a certain lag and error.

The data used in this research refer to Swedish regions with similar long-run behaviour concerning unemployment. The short-run behaviour should be heterogeneous because of region-specific gaps. Therefore, for this particular case, the PMG estimator should be the best choice.

The significance of each estimator is checked using the Hausman test. When there are enough lags for the variables in the model, the endogeneity issue is alleviated by MG and PMG type estimators (Pesaran et al., 1999).

The contemporaneous correlation is considered by including the common correlated effect in the model. The common factor is controlled through the cross-sectional means of regressors. We expect the Common Correlated Effect Mean Group estimator to be efficient and consistent in this case under the null assumption stating homogeneity in the long term (Pesaran, 2006).

The asymmetric short and long-run connection is taken into account in the nonlinear type ARDL estimator proposed by Shin et al. (2014). We may expect a quite asymmetric response of job searches on unemployment.

This procedure supposes decomposition of the analysed variable into both positive and negative subvariables, defined by index+ and index- as incomplete sums of direct and inverse modifications in job searches.

$$
\begin{aligned}
& \log \_u r_{i t}=\alpha_{i}+\sum_{l=1}^{p} \beta_{0} \log \_u r_{i t-l} \\
& +\sum_{l=0}^{q-1}\left(\beta_{1} \log _{-} \text {index } x_{i t-l}^{+}+\beta_{2} \log \text { index }_{i t-l}^{-}\right)+\sum_{l=0}^{q} \beta_{3} \log { }_{-} G D P_{i t-l}+e_{i t}
\end{aligned}
$$

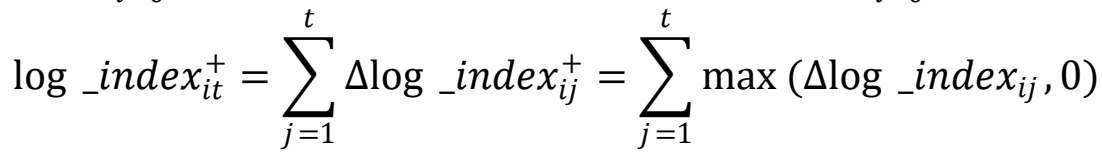

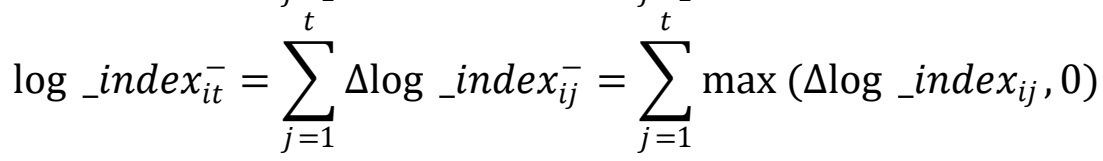

The reparametrisation of the previous equation generates: 


$$
\begin{aligned}
& \Delta \log \_u r_{i t}=\alpha_{i}+\Phi_{i}\left(\log { }_{2} u r_{i t-l}-\theta_{1} \log \text { index }_{i t-l}^{+}-\theta_{2} \log \text { index }_{i t-l}^{-}-\theta_{3} \log \_G D P_{i t-l}\right) \\
& +\sum_{l=1}^{p-1} \lambda_{1} \Delta \log \_u r_{i t-l} \\
& +\sum_{l=0}^{q-1}\left(\lambda_{2} \Delta \text { index } x_{i t-l}^{+}+\lambda_{3} \Delta \text { index } \overline{i t}-l_{-l}^{-}\right)+\sum_{l=0}^{q-1} \lambda_{4} \Delta \log { }_{-} G D P_{i t-l}+e_{i t}
\end{aligned}
$$

In this research, the approach based on PMG and the CCEPMG estimators is considered to reflect the crosssectional dependence.

\section{Empirical Results}

Panel unit root tests were applied for variables in the model, and the final results are presented in Tab. 1, the

\begin{tabular}{|c|c|c|c|c|c|c|}
\hline Variable & \multicolumn{2}{|c|}{$\begin{array}{l}\text { IPS test (H0: panel } \\
\text { contains unit roots ) }\end{array}$} & \multicolumn{2}{|c|}{$\begin{array}{l}\text { LLC test (H0: panel } \\
\text { includes unit-roots) }\end{array}$} & \multicolumn{2}{|c|}{$\begin{array}{l}\text { CIPS test (H0: homogeneous non- } \\
\text { stationary) }\end{array}$} \\
\hline log_ur & $\begin{array}{l}\text { Intercept } \\
-3.0054 \\
(0.0013)\end{array}$ & $\begin{array}{l}\text { Intercept }+ \\
\text { trend } \\
-2.9912 \\
(0.0014)\end{array}$ & $\begin{array}{c}\text { Intercept } \\
\\
4.3850 \\
(1.0000)\end{array}$ & $\begin{array}{l}\text { Intercept }+ \\
\text { trend } \\
-3.7861 \\
(0.0001)\end{array}$ & $\begin{array}{l}\text { Intercept } \\
-3.260\end{array}$ & $\begin{array}{l}\text { Intercept }+ \\
\text { trend } \\
\quad-2.510\end{array}$ \\
\hline log_GDP & $\begin{array}{c}5.7051 \\
(1.0000)\end{array}$ & $\begin{array}{l}-2.9377 \\
(0.0017)\end{array}$ & $\begin{array}{c}2.7886 \\
(0.9974)\end{array}$ & $\begin{array}{l}0.5660 \\
(0.7143)\end{array}$ & $\begin{array}{l}{[-2.37]} \\
-2.431\end{array}$ & $\begin{array}{l}{[-2.93]} \\
-3.051\end{array}$ \\
\hline $\log _{-}$job & $\begin{array}{l}-3.1156 \\
(0.0009)\end{array}$ & $\begin{array}{l}-3.0722 \\
(0.0011)\end{array}$ & $\begin{array}{l}-1.1157 \\
(0.1323)\end{array}$ & $\begin{array}{l}-1.5558 \\
(0.0599)\end{array}$ & $\begin{array}{l}{[-2.37]} \\
-2.872\end{array}$ & $\begin{array}{l}{[-2.93]} \\
-3.489\end{array}$ \\
\hline $\begin{array}{l}\text { (logarithm of } \\
\text { Google Trends index } \\
\text { for 'job') }\end{array}$ & & & & & {$[-2.37]$} & {$[-2.92]$} \\
\hline $\begin{array}{c}\log \text { Jobnet } \\
\text { (logarithm of Google }\end{array}$ & $\begin{array}{l}-3.2991 \\
(0.0005)\end{array}$ & $\begin{array}{l}-3.2584 \\
(0.0006)\end{array}$ & $\begin{array}{l}-6.1416 \\
(0.0000)\end{array}$ & $\begin{array}{l}-4.6883 \\
(0.0000)\end{array}$ & -3.104 & -2.900 \\
\hline $\begin{array}{l}\text { Trends index for } \\
\text { 'Jobnet') }\end{array}$ & & & & & {$[-2.37]$} & {$[-2.93]$} \\
\hline $\begin{array}{c}\log \text { _jobindex } \\
\text { (logarithm of Google }\end{array}$ & $\begin{array}{l}-2.8597 \\
(0.0021)\end{array}$ & $\begin{array}{l}-3.3071 \\
(0.0005)\end{array}$ & $\begin{array}{l}-3.4572 \\
(0.0003)\end{array}$ & $\begin{array}{l}-4.9759 \\
(0.0000)\end{array}$ & -3.370 & -2.984 \\
\hline $\begin{array}{l}\text { Trends index for } \\
\text { (jobindex.dk') }\end{array}$ & & & & & {$[-2.37]$} & {$[-2.37]$} \\
\hline $\begin{array}{c}\text { log_ofir } \\
\text { (logarithm of Google }\end{array}$ & $\begin{array}{l}-2.6464 \\
(0.0041)\end{array}$ & $\begin{array}{l}-2.6398 \\
(0.0041)\end{array}$ & -4.2234 & -3.4738 & -2.94 & -2.46 \\
\hline $\begin{array}{l}\text { Trends index for } \\
\text { 'ofir.dk') }\end{array}$ & & & $(0.000)$ & $(0.003)$ & {$[-2.37]$} & {$[-2.37]$} \\
\hline $\begin{array}{l}\text { log_ur in first } \\
\text { difference }\end{array}$ & $\begin{array}{l}-3.0054 \\
(0.0013)\end{array}$ & $\begin{array}{l}-2.9912 \\
(0.0014)\end{array}$ & $\begin{array}{l}-2.7804 \\
(0.0027)\end{array}$ & $\begin{array}{l}-3.7861 \\
(0.0001)\end{array}$ & -3.260 & -2.960 \\
\hline $\begin{array}{l}\text { log_GDP in } \\
\text { first difference }\end{array}$ & $\begin{array}{l}-2.9765 \\
(0.0014)\end{array}$ & $\begin{array}{l}-2.9377 \\
(0.0017)\end{array}$ & -3.0834 & -3.0922 & $\begin{array}{l}{[-2.37]} \\
-2.431\end{array}$ & $\begin{array}{l}{[-2.93]} \\
-3.051\end{array}$ \\
\hline $\begin{array}{l}\text { log_job in first } \\
\text { difference }\end{array}$ & $\begin{array}{l}-3.1615 \\
0.0008\end{array}$ & $\begin{array}{l}-3.5939 \\
0.0002\end{array}$ & $\begin{array}{c}(0.0013) \\
-3.1190 \\
0.0009\end{array}$ & $\begin{array}{l}(0.0013) \\
-2.9823 \\
0.0014\end{array}$ & $\begin{array}{l}{[-2.37]} \\
-2.450\end{array}$ & $\begin{array}{l}{[-2.93]} \\
-3.342\end{array}$ \\
\hline & & & & & {$[-2.37]$} & {$[-2.93]$} \\
\hline
\end{tabular}
chosen level of significance being $5 \%$.

Tab. 1. The results of stationarity tests

The results based on these tests are contradictory. The data series for GDP in logarithmic values are integrated in the order of 1 . The unemployment rate in logarithmic values is stationary based on IPS but presents unit root according to CIPS and LLC. According to LLC, the Google Trends index for the job in logarithmic values is stationary using IPS and CIPS, but with a unit root. The data series are stationary in level for the rest of the indexes based on the unit root tests. Therefore, co-integration tests between unemployment and Google indexes should be applied to verify the possible presence of a long-term connection.

This long-term connection is studied by implementing three co-integration tests: Pedroni test, Kao test and Westerlund test for $1 \%$ level of significance (Tab. 2). 


\begin{tabular}{|c|c|c|c|c|c|c|c|c|c|c|}
\hline Kao test & $\begin{array}{c}\text { Statisti } \\
\text { c }\end{array}$ & $\begin{array}{c}\mathrm{p}- \\
\text { value }\end{array}$ & $\begin{array}{c}\text { Pedroni } \\
\text { test }\end{array}$ & $\begin{array}{c}\text { Statisti } \\
\text { c }\end{array}$ & $\begin{array}{c}\mathrm{p}- \\
\text { value }\end{array}$ & $\begin{array}{c}\text { Westerlund } \\
\text { cointegratio } \\
\mathrm{n}\end{array}$ & Constant & & $\begin{array}{l}\text { Constant } \\
\text { and trend }\end{array}$ & \\
\hline $\begin{array}{l}\text { Modified } \\
\text { Dickey- } \\
\text { Fuller t }\end{array}$ & 1.4171 & $\begin{array}{c}0.078 \\
2\end{array}$ & & & & & Statistic & $\begin{array}{c}\mathrm{p}- \\
\text { value }\end{array}$ & Statistic & $\begin{array}{c}\mathrm{p}- \\
\text { value }\end{array}$ \\
\hline $\begin{array}{l}\text { Dickey- } \\
\text { Fuller t }\end{array}$ & 1.9293 & $\begin{array}{c}0.026 \\
8\end{array}$ & $\begin{array}{l}\text { Modified } \\
\text { Phillips- } \\
\text { Perron }\end{array}$ & 0.7148 & $\begin{array}{c}0.237 \\
4\end{array}$ & $\begin{array}{c}\text { Variance } \\
\text { ratio }\end{array}$ & $2^{1.281}$ & $\begin{array}{c}0.100 \\
1\end{array}$ & $9^{1.516}$ & $\begin{array}{c}0.064 \\
6\end{array}$ \\
\hline $\begin{array}{c}\text { Augmente } \\
\text { d Dickey- } \\
\text { Fuller t }\end{array}$ & 1.0637 & $\begin{array}{c}0.143 \\
7\end{array}$ & $\begin{array}{c}\text { Augmente } \\
\text { d Dickey- } \\
\text { Fuller t }\end{array}$ & 1.8045 & $\begin{array}{c}0.035 \\
6\end{array}$ & & & & & \\
\hline $\begin{array}{l}\text { Unadjusted } \\
\text { modified } \\
\text { Dickey- } \\
\text { Fuller t }\end{array}$ & 1.4171 & $\begin{array}{c}0.078 \\
2\end{array}$ & & & & & & & & \\
\hline $\begin{array}{c}\text { Unadjusted } \\
\text { Dickey- } \\
\text { Fuller t }\end{array}$ & 1.9293 & $\begin{array}{c}0.026 \\
8\end{array}$ & & & & & & & & \\
\hline
\end{tabular}

Source: own computations in Stata 16

According to the Pedroni test, the null assumption in a heterogeneous panel is not rejected at a $1 \%$ level of significance. The same result is obtained using Kao and Westerlund tests.

In the case of non-stationary and non-cointegrated panel data series, the relationships could be identified using the panel ARDL model. In this study, three methods were applied: MG, PMG and TWFE.

A negative and significant error correction term for PMG, MD and TWFE models indicates that these models converge to a long-term relationship. There is only a short-run connection between Google searches for "job" and unemployment in Denmark at a 10\% level of significance. There is a negative correlation between these indicators, which suggests that more searches for jobs on the Internet contribute to a reduction of unemployment in the shortrun. On the other hand, there is an inverse long-run connection between unemployment and output, which is confirmed by economic theory (Okun law).

Analysing the values of all the error correction terms, the maximum adjustment speed of $67.4 \%(-0.674)$ is obtained from PMG for the second type of model, which suggests a particular correction of $67.4 \%$ in the case of estimation discrepancy (see Tab. 3).

\begin{tabular}{|c|c|c|c|c|c|c|c|}
\hline & Variable (in log) & PMG1 & MG1 & TWFE1 & PMG2 & MG2 & TWFE2 \\
\hline \multirow[t]{2}{*}{$\begin{array}{l}\text { Long-run } \\
\text { relationship }\end{array}$} & Log_job & $7.342(0.000)$ & $2.333(0.000)$ & $\begin{array}{c}0.648 \\
(0.564)\end{array}$ & $0.805(0.810)$ & $0.783(0.115)$ & $\begin{array}{c}0.703 \\
(0.133)\end{array}$ \\
\hline & Log_GDP & - & - & - & $\begin{array}{l}-2.051 \\
(0.000)\end{array}$ & $\begin{array}{l}-2.002 \\
(0.000)\end{array}$ & $\begin{array}{l}-1.975 \\
(0.000)\end{array}$ \\
\hline $\begin{array}{c}\text { Error } \\
\text { correction term }\end{array}$ & & $-0.374(0.005)$ & $\begin{array}{l}-0.455 \\
(0.002)\end{array}$ & $\begin{array}{l}-0.637 \\
(0.000)\end{array}$ & $\begin{array}{l}-0.674 \\
(0.000)\end{array}$ & $\begin{array}{l}-0.655 \\
(0.000)\end{array}$ & $\begin{array}{l}-0.648 \\
(0.000)\end{array}$ \\
\hline \multirow[t]{3}{*}{$\begin{array}{l}\text { Short-term } \\
\text { relationship }\end{array}$} & Log_job & $-1.586(0.000)$ & $\begin{array}{l}-0.934 \\
(0.001)\end{array}$ & $\begin{array}{l}-0.317 \\
(0.052)\end{array}$ & $\begin{array}{l}-0.118 \\
(0.092)\end{array}$ & $\begin{array}{l}-0.122 \\
(0.087)\end{array}$ & $\begin{array}{l}-0.197 \\
(0.035)\end{array}$ \\
\hline & Log_GDP & - & - & - & $0.367(0.023)$ & $0.344(0.032)$ & $\begin{array}{c}0.276 \\
(0.428)\end{array}$ \\
\hline & Constant & $\begin{array}{l}-11.793 \\
(0.005)\end{array}$ & $\begin{array}{l}-5.456 \\
(0.033)\end{array}$ & $\begin{array}{l}-0.680 \\
(0.834)\end{array}$ & $\begin{array}{l}15.916 \\
(0.000)\end{array}$ & $\begin{array}{l}14.332 \\
(0.000)\end{array}$ & $\begin{array}{l}12.497 \\
(0.000)\end{array}$ \\
\hline Residuals & & & & Stationary & & & \\
\hline
\end{tabular}

The panel ARDL approach reduces the issue of endogeneity, which might be a problem in the correlation between unemployment and Internet searches (Pesaran \& Smith, 1999). The PMG estimator is expected to be the best method. This estimator allows different responses across regions in the short-run, but non-heterogeneity is present in the long-run. The main benefits of the PMG approach are related to the small number of cross-sections (only 5 countries in this case), simultaneous correction of serial correlation and low sensitivity to the presence of outliers.

The long-run restriction is accepted since homogeneity restriction is significant and efficient under this assumption. The Hausman test used to choose between MG and PMG models suggests the superiority of the PMG approach (stat.=1.01 with p-value=0.55). The regressions are not spurious. The series of residuals are stationary in all cases.

The ARDL approach does not take into account the existence of contemporaneous correlation across regions determined by unobserved factors. Less consistent coefficients are obtained by ignoring these factors (Baltagi, 
2014). The Pesaran CD test indicates a significant cross-sectional dependence on errors. The contemporaneous correlation will reduce if the common correlated approach is considered.

Tab. 4 suggests that the CCEPMG estimator reveals significant and negative error correction terms in the long and short term. There is a negative connection between unemployment and Google searches for jobs both in the long and short term. On the other hand, the unemployment rate is negatively correlated with GDP on both terms, the economic expectations being reached.

\begin{tabular}{llllll}
\multicolumn{5}{l}{ Tab. 4. The panel ARDL estimation results based on common correlated effect in case of Google searches for "job" } \\
\hline & Variable (in log) & CCEPMG1 & CCEMG1 & PMG2 & CCEMG2 \\
\hline $\begin{array}{l}\text { Long-term } \\
\text { relationship }\end{array}$ & Log_job & $-0.153(0.003)$ & $-0.095(0.102)$ & $-0.105(0.002)$ & $-0.088(0.060)$ \\
& Log_GDP & - & - & $-1.332(0.000)$ & $-1.455(0.000)$ \\
Error correction & & $-0.506(0.020)$ & $-0.433(0.002)$ & $-0.766(0.000)$ & $-0.706(0.000)$ \\
$\begin{array}{l}\text { Short-run } \\
\text { relationship }\end{array}$ & Log_job & $-0.061(0.000)$ & $-0.055(0.000)$ & $-0.098(0.060)$ & $-0.046(0.052)$ \\
& Log_GDP & - & - & $0.093(0.022)$ & $0.0678(0.004)$ \\
& Constant & $2.234(0.067)$ & $3.337(0.002)$ & $5.221(0.000)$ & $4.985(0.000)$ \\
Residuals & \multicolumn{4}{c}{ Stationary } \\
\hline
\end{tabular}

In the case of deviation from long-term, the adjustment speed to the equilibrium is given by the error correction term in absolute value. The rate of correction in the bivariate model is $50.6 \%$ according to the CCEPMG approach and $43.3 \%$ according to CCEMG. This speed of adjustment is higher in the case of the multivariate model: $76.6 \%$ (CCEPMG) and 70.6\% (CCEMG).

The residuals are stationary in all cases, and the CCE estimator is relevant even if the errors are serially correlated (Pesaran, 2006). However, despite the significant results for CCEPMG, the cross-sectional dependence is present in the other cases. According to Chudik and Pesaran (2015), two conditions should be fulfilled by CCEMG estimator:

a) enough lags in cross-section means should be considered;

b) the number of unobserved common factors is lower than the number of regions averages.

In the research, the sample is small, and more lags will not be considered. The CCEMG estimator is preferred in this analysis due to correct specification and the lack of issues related to cross-sectional dependence and serial correlation.

The results of the nonlinear panel ARDL model are presented in Tab. 5. The Wald test was used to check if there is a nonlinear long and short-run response of changes in job searches on the unemployment rate. According to the PMG estimator, an asymmetric relationship of change in job searches in the short-term could not be distinguished since the coefficients associated with job searches (+) and job searches (-) are negative. The symmetric relationship in the long and short horizon is not rejected using the Wald test. In the case of the CCEPMG approach that controls for the dependence in regions, there is a significant asymmetry only in the short-term. The results based on the Wald test are not false since the errors are stationary.

\begin{tabular}{|c|c|c|c|}
\hline & Variables & PMG estimator & $\begin{array}{l}\text { CCEPMG } \\
\text { approach }\end{array}$ \\
\hline \multirow[t]{3}{*}{$\begin{array}{l}\text { Long-term } \\
\text { connection }\end{array}$} & Log_job $(+)$ & $\begin{array}{l}-0.642 \\
(0.003)\end{array}$ & $-0.143(0.025)$ \\
\hline & Log_job (-) & $0.722(0.045)$ & $-0.599(0.003)$ \\
\hline & Log_GDP & $0.875(0.112)$ & $-0.103(0.035)$ \\
\hline Error correction & & $-0.203(0.018)$ & $-0.733(0.022)$ \\
\hline Short-run & Log_job $(+)$ & $-0.061(0.000)$ & $-0.055(0.000)$ \\
\hline \multirow[t]{3}{*}{ relationship } & $\log _{-}$job (-) & $-0.104(0.056)$ & $-0.062(0.145)$ \\
\hline & Log_GDP & $-0.083(0.144)$ & $-0.024(0.030)$ \\
\hline & Constant & $2.234(0.067)$ & $3.337(0.002)$ \\
\hline Residuals & $\mathrm{I}(0)$ & $\mathrm{I}(0)$ & $\mathrm{I}(0)$ \\
\hline $\mathrm{CD}$ & & 1.56 & -0.83 \\
\hline $\mathrm{AR}$ & & 2.86 & 6.33 \\
\hline RMSE & & 0.034 & 0.019 \\
\hline $\begin{array}{l}\text { Adjusted R- } \\
\text { square }\end{array}$ & & 0.875 & 0.762 \\
\hline WLR & & $1.56(0.220)$ & $0.55(0.435)$ \\
\hline WSR & & $1.56(0.220)$ & $2.99(0.08)$ \\
\hline
\end{tabular}

In the short-run, the indirect effect of job searches supposes higher chances to receive a job that will reduce the unemployment tension in Denmark's regions. The growth of job searches by $1 \%$ lowers the unemployment 
rate by 0.055 to $0.061 \mathrm{pp}$. in the short-term. However, in the long-run, the amplitude of specific regimes is higher (by 0.143 to $0.642 \mathrm{pp}$ ), showing that more searches for jobs in Denmark will significantly reduce the unemployment rate.

More asymmetric panel ARDL models are constructed for other keywords reflecting Google searches (Tab. 6). Similar results are obtained using the other keywords. The maximum reduction in unemployment in the long and short term was obtained in the case of searches based on 'jobindex' (the positive $1 \%$ growth rate of searches based on 'jobindex' will lower the unemployment rate by 0.05 to $0.167 \mathrm{pp}$ in the long term and by 0.051 to 0.061 ).

\begin{tabular}{|c|c|c|c|c|c|c|c|c|c|}
\hline & $\begin{array}{l}\text { Variable } \\
\text { (in log) }\end{array}$ & PMG & $\begin{array}{c}\text { CCEPM } \\
\text { G }\end{array}$ & $\begin{array}{c}\text { Variable (in } \\
\log \text { ) }\end{array}$ & PMG & CCEPMG & $\begin{array}{l}\text { Variable } \\
\text { (in log) }\end{array}$ & PMG & $\begin{array}{c}\text { CCEPM } \\
\text { G }\end{array}$ \\
\hline $\begin{array}{l}\text { Long-run } \\
\text { relationshi } \\
\text { p }\end{array}$ & $\begin{array}{c}\text { Log_Jobne } \\
\mathrm{t}(+)\end{array}$ & $\begin{array}{c}- \\
0.0188 \\
(0.020 \\
)\end{array}$ & $\begin{array}{l}-0.063 \\
(0.050)\end{array}$ & $\begin{array}{c}\text { Log_jobindex } \\
)\end{array}$ & $\begin{array}{c}-0.056 \\
(0.029 \\
)\end{array}$ & $\begin{array}{l}-0.167 \\
(0.020)\end{array}$ & $\begin{array}{c}\text { Log_ofir } \\
(+)\end{array}$ & $\begin{array}{l}-0.050 \\
(0.001)\end{array}$ & $\begin{array}{l}-0.143 \\
(0.043)\end{array}$ \\
\hline \multirow{2}{*}{$\mathrm{p}$} & $\begin{array}{c}\text { Log_Jobne } \\
\text { t (-) }\end{array}$ & $\begin{array}{c}0.335 \\
(0.064 \\
)\end{array}$ & $\begin{array}{l}-0.223 \\
(0.044)\end{array}$ & $\begin{array}{c}\text { Log_jobindex (- } \\
\text { ) }\end{array}$ & $\begin{array}{c}0.114 \\
(0.078 \\
)\end{array}$ & $\begin{array}{l}-0.021 \\
(0.749)\end{array}$ & $\underset{(-)}{\log \text { ofir }}$ & $\begin{array}{c}0.443 \\
(0.055)\end{array}$ & $\begin{array}{l}-0.097 \\
(0.332)\end{array}$ \\
\hline & Log_GDP & $\begin{array}{c}1.948 \\
(0.204 \\
)\end{array}$ & $\begin{array}{l}-1.973 \\
(0.000)\end{array}$ & Log_GDP & $\begin{array}{c}0.875 \\
(0.112 \\
)\end{array}$ & $\begin{array}{l}-2.007 \\
(0.000)\end{array}$ & $\underset{\mathrm{P}}{\log G D}$ & $\begin{array}{c}0.898(0.110 \\
)\end{array}$ & $\begin{array}{l}-2.324 \\
(0.035)\end{array}$ \\
\hline $\begin{array}{c}\text { Error } \\
\text { correction } \\
\text { term }\end{array}$ & & $\begin{array}{c}-0.677 \\
(0.000 \\
)\end{array}$ & $\begin{array}{l}-0.649 \\
(0.000)\end{array}$ & & $\begin{array}{c}-0.668 \\
(0.000 \\
)\end{array}$ & $\begin{array}{l}-0.642 \\
(0.000)\end{array}$ & & $\begin{array}{l}-0.661 \\
(0.018)\end{array}$ & $\begin{array}{l}-0.681 \\
(0.000)\end{array}$ \\
\hline \multirow[t]{4}{*}{$\begin{array}{c}\text { Short-run } \\
\text { relationshi } \\
\text { p }\end{array}$} & $\begin{array}{c}\text { Log_Jobne } \\
t(+)\end{array}$ & $\begin{array}{c}-0.033 \\
(0.000 \\
)\end{array}$ & $\begin{array}{l}-0.026 \\
(0.000)\end{array}$ & $\begin{array}{c}\log _{-} \text {jobindex } \\
(+)\end{array}$ & $\begin{array}{c}-0.061 \\
(0.000 \\
)\end{array}$ & $\begin{array}{l}-0.051 \\
(0.000)\end{array}$ & $\begin{array}{c}\text { Log_ofir } \\
(+)\end{array}$ & $\begin{array}{l}-0.024 \\
(0.026)\end{array}$ & $\begin{array}{l}-0.031 \\
(0.025)\end{array}$ \\
\hline & $\begin{array}{c}\text { Log_Jobne } \\
\text { t (-) }\end{array}$ & $\begin{array}{c}-0.104 \\
(0.056 \\
)\end{array}$ & $\begin{array}{c}0.073 \\
(0.134)\end{array}$ & $\begin{array}{c}\text { Log_jobindex (- } \\
\text { ) }\end{array}$ & $\begin{array}{c}0.104 \\
(0.056 \\
)\end{array}$ & $\begin{array}{l}-0.078 \\
(0.220)\end{array}$ & $\begin{array}{c}\text { Log_ofir } \\
-)\end{array}$ & $\begin{array}{l}-0.120 \\
(0.05)\end{array}$ & $\begin{array}{c}0.102 \\
(0.055)\end{array}$ \\
\hline & Log_GDP & $\begin{array}{c}-0.021 \\
(0.440 \\
)\end{array}$ & $\begin{array}{l}-0.023 \\
(0.030)\end{array}$ & Log_GDP & $\begin{array}{c}-0.083 \\
(0.144 \\
)\end{array}$ & $\begin{array}{l}-0.221 \\
(0.506)\end{array}$ & $\underset{\mathrm{P}}{\log G D}$ & $\begin{array}{l}-0.031 \\
(0.354)\end{array}$ & $\begin{array}{l}-0.0858 \\
(0.076)\end{array}$ \\
\hline & Constant & $\begin{array}{c}4.892 \\
(0.000 \\
)\end{array}$ & $\begin{array}{c}4.396 \\
(0.002)\end{array}$ & Constant & $\begin{array}{c}2.234 \\
(0.067 \\
)\end{array}$ & $\begin{array}{c}4.594(0.000 \\
)\end{array}$ & Constant & $4.35(0.067)$ & $\begin{array}{c}7.667 \\
(0.000)\end{array}$ \\
\hline Residuals & & & & & Statio & & & & \\
\hline $\mathrm{CD}$ & & 1.89 & -0.97 & & 1.56 & -0.85 & & 1.68 & -0.99 \\
\hline $\mathrm{AR}$ & & 2.36 & 7.21 & & 2.86 & 6.23 & & 2.93 & 5.80 \\
\hline RMSE & & 0.028 & 0.022 & & 0.034 & 0.02 & & 0.033 & 0.023 \\
\hline Adjusted & & 0.890 & 0.792 & & 0.875 & 0.732 & & 0.803 & 0.668 \\
\hline \multicolumn{10}{|l|}{ R-square } \\
\hline WLR & & $\begin{array}{c}1.80 \\
(0.430 \\
)\end{array}$ & $\begin{array}{c}0.559 \\
(0.405)\end{array}$ & & $\begin{array}{c}1.56 \\
(0.220 \\
)\end{array}$ & $0.51(0.430)$ & & $1.33(0.220)$ & $\begin{array}{c}0.49 \\
(0.402)\end{array}$ \\
\hline WSR & & $\begin{array}{c}1.80 \\
(0.430 \\
)\end{array}$ & $\begin{array}{c}3.66 \\
(0.06)\end{array}$ & & $\begin{array}{c}1.56 \\
(0.220 \\
)\end{array}$ & $\begin{array}{c}3.02 \\
(0.07)\end{array}$ & & $1.33(0.220)$ & $\begin{array}{c}3.15 \\
(0.07)\end{array}$ \\
\hline
\end{tabular}

All in all, the searches based on the keyword 'job' have the highest impact on unemployment, an increase in this Google index generating a higher reduction in unemployment. An interesting approach is to analyse the situation in each region, considering this keyword. Only a part of the estimations will be presented in Tab. 7 for each region to indicate the magnitude of the short-run impact of job searches on unemployment.

Tab. 7. The short-run impact of searches for 'job' on unemployment rate in Danish region

\begin{tabular}{ccc}
\hline Region & PMG & CCEPMG \\
\hline Hovedstaden & $-0.993(0.009)$ & $-1.002(0.000)$ \\
Midtjylland & $-0.344(0.092)$ & $-0.403(0.08)$ \\
Nordjylland & $-0.603(0.009)$ & $-0.772(0.006)$ \\
Sjä́lland & $-0.624(0.008)$ & $-0.678(0.006)$ \\
Syddanmark & $0.076(0.859)$ & $0.098(0.822)$ \\
\hline
\end{tabular}

Source: own computations in Stata 16

It is interesting that we have a positive sign in the case of the Syddanmark region, which indicates an increase in unemployment even if searches for a job are more in the short run. This region is characterised by high longrun unemployment compared to other regions and by a high youth unemployment rate. Syddanmark region is recognised for its low innovation performance. It has been strongly affected by the recent financial crisis mostly because it has many small companies oriented through exports (European Commission, 2020). However, in all the 
cases, the error correction terms are negative, which suggests an inverse long-run connection between unemployment and search for 'job' for all regions.

The forecasts for economic growth at regional level on the horizon Q1:2021-Q4:2021. For the first quarter of 2021, a decline in output is anticipated for all the regions, but for the second quarter, only Syddanmark and Midtjylland will register a decrease in economic activity. The forecasts for the last two quarters of 2021 are made under the assumption of the same change in unemployment as in the first two quarters of 2021. Point forecasts are not provided here since our objective is not to provide accurate forecasts but to anticipate an increase or decrease in output.

\section{Conclusions}

The COVID-19 pandemic accelerated the recent tendency to combine the data provided by official statistics with Internet data, technology miniaturisation and social media (Askitas \& Zimmermann, 2011). Google Trends offers aggregated data in real-time for certain keywords, but the boundaries are not mentioned by Google (Askitas \& Zimmermann, 2009a).

Besides easy access to Internet data that are well economical and digitally organised, this approach allows us to observe behavioural trends in countries with high Internet penetration rates like Denmark.

In this context, we proved the utility of the Internet in searching for jobs in Denmark. Unlike most of the previous studies, a regional approach was proposed. Our empirical findings were in line with results for developed countries. The unemployment rate in Denmark at the regional level is correlated with searches on the Internet, which proves the efficiency of this tool in reducing the unemployment period. More searches on the Internet will reduce the unemployment rate in the long-run and short-run. This conclusion is fundamental for the digital economy policy at the EU level. In this case, Denmark could serve as a model for other EU countries that should establish national coalitions for digital jobs and develop digital competencies for small businesses. The coronavirus epidemic demonstrates the essential importance of digital solutions and networks for resilience and citizens' wellbeing.

Particular attention should be assigned to the utilisation of Google Trends to improve employability in sectors that are less developed. For example, there are no active mines in Denmark, but political initiatives should be implemented to develop this sector. The other Nordic countries like Finland, Sweden, Greenland, and Norway express their interest in developing the mining sector. Besides the technical issues related to planned mines, the policymakers should take measures to employ human resources in this sector. Google Trends could help them in detecting regions with the highest unemployment rates, and mines could be constructed in these regions as it is possible. On the other hand, people could use the Internet to search for a job in this sector.

Limits of the research might be given by the fact that the proposed models could be improved by adding other variables. For example, a dummy variable could be added to show for each year if it was a period of economic crisis or not. During the economic crisis, the unemployment rates are higher than in other periods. More control variables could be added to the models, but we are limited by data availability at the NUTS 2 level.

Another limitation is related to the lack of causality between Google searches and unemployment. Our approach allows us to establish an association between variables in order to make nowcasts or forecasts of the unemployment rate in real-time.

\section{References}

Andersen, T. M. (2019). Labour market policies in Denmark.

Askitas, N. (2015). Google search activity data and breaking trends. IZA World of Labor.

Askitas, N., \& Zimmermann, K. F. (2009a). Google econometrics and unemployment forecasting. Applied Economics Quarterly, 55(2), 107-120. https://doi.org/10.3790/aeq.55.2.107

Askitas, N., \& Zimmermann, K. F. (2009b). Googlemetrie und Arbeitsmarkt. Wirtschaftsdienst, 89 (7), $489-496$.

Barreira, N., Godinho, P., \& Melo, P. (2013). Nowcasting unemployment rate and new car sales in south-western Europe with Google Trends. NETNOMICS: Economic Research and Electronic Networking, 14(3), 129165. https://doi.org/10.1007/s11066-013-9082-8

Billari, F., D’Amuri, F., \& Marcucci, J. (2013). Forecasting births using Google. Annual Meeting of the Population Association of America, PAA, New Orleans, LA.

Caperna, G., Colagrossi, M., Geraci, A., \& Mazzarella, G. (2020). Googling Unemployment During the Pandemic: Inference and Nowcast Using Search Data. Available at SSRN 3627754.

Carrière-Swallow, Y., \& Labbé, F. (2013). Nowcasting with Google Trends in an emerging market. Journal of Forecasting, 32(4), 289-298. https://doi.org/10.1002/for.1252

Chadwick, M. G., \& Sengül, G. (2015). Nowcasting the Unemployment Rate in Turkey: Let's Ask Google. Central Bank Review, 15(3), 15. https://doi.org/10.1016/j.frl.2019.04.005 
Chen, T., So, E. P. K., Wu, L., \& Yan, I. K. M. (2015). The 2007-2008 US Recession: What Did the Real-Time Google Trends Data Tell the United States?. Contemporary Economic Policy, 33(2), 395-403. https://doi.org/10.1111/coep.12074

Choi, H., \& Varian, H. (2009). Predicting initial claims for unemployment benefits. Google Inc, 1-5.

Choi, H., \& Varian, H. (2012). Predicting the present with Google Trends. Economic Record, 88(s1), 2-9. https://doi.org/10.1111/j.1475-4932.2012.00809.x

Claveria O (2019) Forecasting the unemployment rate using the degree of agreement in consumer unemployment expectations. Journal of Labour Market Research, 53(3), 1-10. https://doi.org/10.1186/s12651-019-0253$\underline{4}$

Constant, A., \& Zimmermann, K. F. (2008). Im Angesicht der Krise: US-Präsidentschaftswahlen in transnationaler Sicht. DIW Wochenbericht, 44, 688-701.

D'Amuri, F., \& Marcucci, J. (2017). The predictive power of Google searches in forecasting US unemployment. International Journal of Forecasting, 33(4), 801-816. https://doi.org/10.1016/j.ijforecast.2017.03.004

D'Amuri, F. (2009). Predicting unemployment in short samples with Internet job search query data. University Library of Munich, Germany.

Dávalos, J. (2015). Now-And Forecasting Unemployment from Google's Job-Search Activity. Available at SSRN 3038007.

Dilmaghani, M. (2019). Workopolis or The Pirate Bay: What Does Google Trends Say about the Unemployment Rate?. Journal of Economic Studies, 00-00.

Dumitrescu, E. I., \& Hurlin, C. (2012). Testing for Granger non-causality in heterogeneous panels. Economic modelling, 29(4), 1450-1460. https://doi.org/10.1016/j.econmod.2012.02.014

Erhvervsråd, A. (2018). 160.000 personer er ikke i job eller uddannelse og får ikke understøttelse. København: Arbejderbevægelsens Erhvervsråd.

Ettredge, M., Gerdes, J., \& Karuga, G. (2005). Using web-based search data to predict macroeconomic statistics. Communications of the ACM, 48(11), 87-92. https://doi.org/10.1145/1096000.1096010

European Commission (2019). Monitoring progress in national initiatives on digitising industry. Country report for Denmark. Retrieved from: https://ec.europa.eu/digital-single-market/en/news/workshop-monitoringprogress-national-initiatives-digitising-industry

European Commission (2020). Internal Market, Industry, Entrepreneurship and SMEs. Retrieved from: https://ec.europa.eu/growth/tools-databases/regional-innovation-monitor/base-profile/southern-denmarkregion

Fantazzini, D. (2014). Nowcasting and Forecasting the Monthly Food Stamps Data in the US Using Online Search Data. PloS One, 9(11), e111894. https://doi.org/10.1371/journal.pone.0111894

Foley, P., Sutton, D., Wiseman, I., Green, L., \& Moore, J. (2020). International Digital Economy and Society Index 2020. Publications Office of the European Union: Brussels, Belgium.

Fondeur, Y., \& Karamé, F. (2013). Can Google data help predict French youth unemployment?. Economic Modelling, 30, 117-125. https://doi.org/10.1016/j.econmod.2012.07.017

Francesco, D. A. (2009). Predicting unemployment in short samples with Internet job search query data. MPRA Paper, 18403, 1-18.

Fransen, K., Boussauw, K., Deruyter, G., \& De Maeyer, P. (2018). The relationship between transport disadvantage and employability: Predicting long-term unemployment based on job seekers' access to suitable job openings in Flanders, Belgium. Transportation Research Part A: Policy and Practice. https://doi.org/10.1186/s12651-019-0253-4

Granger, C. W. (1969). Investigating causal relations by econometric models and cross-spectral methods. Econometrica: Journal of the Econometric Society, 424-438.

Jespersen, S. T., Munch, J. R., \& Skipper, L. (2008). Costs and benefits of Danish active labour market programmes. Labour economics, 15(5), 859-884. https://doi.org/10.1016/j.labeco.2007.07.005

Karg1, B. (2016). Okun's Law and long term co-integration analysis for OECD countries (1987-2012). Emerging Markets Journal, 6(1), 39-46. https://doi.org/10.5195/emaj.2016.97

Knudsen, M. P., Christensen, J. L., \& Christensen, P. (2018). RIO Country Report 2017: Denmark. Luxembourg: Publications Office of the European Union.

Lasso, F., \& Snijders, S. (2016). The power of Google search data; an alternative approach to the measurement of unemployment in Brazil. Student Undergraduate Research E-journal!, 2.

Levin, A., Lin, C. F., \& Chu, C. S. J. (2002). Unit root tests in panel data: asymptotic and finite-sample properties. Journal of econometrics, 108(1), 1-24.

McLaren, N., \& Shanbhogue, R. (2011). Using Internet search data as economic indicators. Bank of England Quarterly Bulletin, June 2011.

Mulero, R., \& García-Hiernaux, A. (2021). Forecasting Spanish unemployment with Google Trends and dimension reduction techniques. SERIEs, 1-21. https://doi.org/10.1007/s13209-021-00231-X 
Naccarato, A., Falorsi, S., Loriga, S., \& Pierini, A. (2018). Combining official and Google Trends data to forecast the Italian youth unemployment rate. Technological Forecasting and Social Change, 130, 114-122. https://doi.org/10.1016/j.techfore.2017.11.022

Naccarato, A., Pierini, A., \& Falorsi, S. (2015). Using Google Trend Data To Predict The Italian Unemployment Rate (No. 0203). Department of Economics-University Roma Tre.

Oleksandr, B. (2010). Can Google's search engine be used to forecast unemployment in Ukraine (Doctoral dissertation, Kyiv School of Economics).

Pavlicek, J., \& Kristoufek, L. (2015). Nowcasting unemployment rates with google searches: Evidence from the visegrad group countries. PloS one, 10(5), e0127084. https://doi.org/10.1371/journal.pone.0127084

Pedroni P (1996) Fully modified OLS for heterogeneous cointegrated panels and the case of purchasing power parity. Manuscript, Department of Economics, Indiana University 5,1-45

Pesaran MH (2007) A simple panel unit root test in the presence of cross-section dependence. Journal of Applied Economics, 22(2), 265-312.

Pesaran, M. H., Shin, Y., \& Smith, R. P. (1999). Pooled mean group estimation of dynamic heterogeneous panels. Journal of the American statistical Association, 94(446), 621-634.

Pryymachenko, Y., Fregert, K., \& Andersson, F. N. (2011). The effect of emigration on unemployment: Evidence from the Central and Eastern European EU member states (No. 2011: 32), 1-17.

Rosholm, M., \& Svarer, M. (2009). Kvantitativ evaluering af Alle i gang. Arbejdsmarkedsstyrelsen.

Simionescu M. (2020). Improving unemployment rate forecasts at regional level in Romania using Google Trends. $\begin{array}{lllll}\text { Technological Forecasting } & \text { Social } & \text { Change, } & 155, & 120026 .\end{array}$ https://doi.org/10.1016/j.techfore.2020.120026

Simionescu M. \& Zimmermann K. (2017) Big Data and Unemployment Analysis (大數據和失業分析). Journal of Renmin University of China, 31(6): 2-11

Stewart, K. (2005). Dimensions of well-being in EU regions: Do GDP and unemployment tell us all we need to know?. Social Indicators Research, 73(2), 221-246.

$\mathrm{Su}, \mathrm{Z}$. (2014). Chinese online unemployment-related searches and macroeconomic indicators. Frontiers of Economics in China, 9(4), 573-605.

Suhoy, T. (2009). Query indices and a 2008 downturn: Israeli data. Bank of Israel.

Vicente, M. R., López-Menéndez, A. J., \& Pérez, R. (2015). Forecasting unemployment with Internet search data: Does it help to improve predictions when job destruction is skyrocketing?. Technological Forecasting and Social Change, 92, 132-139. https://doi.org/10.1016/j.techfore.2014.12.005

Westerlund J (2007) Testing for error correction in panel data. Oxford Bulletin of Economic Statistics, 69(6), 709748. https://doi.org/10.26481/umamet.2006056 